\title{
Inhibition of attachment of some fouling diatoms and settlement of Ulva lactuca zoospores by film-forming bacterium and their extracellular products isolated from biofouled substrata in Northern Chile
}

\author{
Fernando Silva-Aciares* \\ Laboratorio de Ecología Microbiana \\ Departamento de Acuicultura \\ Facultad de Recursos del Mar \\ Universidad de Antofagasta \\ Av. Jaime Guzman s/n Casilla 170 \\ Antofagasta, Chile \\ Tel: 5655637881 \\ Fax: 5655637804 \\ E-mail: fsaciares@uantof.cl

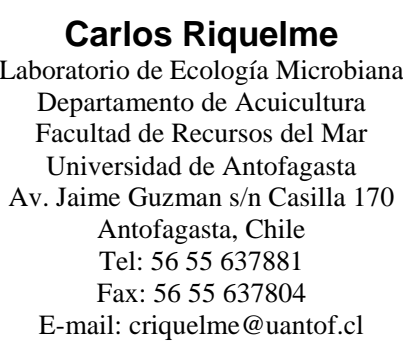

Financial support: This study was possible thanks to the financing of the project FONDEF $\mathrm{N}^{\circ}$ D01I1166 "Development of products of Microbial Origin for the Control of Biofouling in the Industry of Aquaculture" and project FONDEF No D04I1251 "Improvement biotechnology to production and application of microbial bioactive substances inhibitory of the biofouling to the marine industry”.

Keywords: Alteromonas sp, antifouling bacteria, antifouling compounds, diatoms, marine microfouling, Ulva zoospores.

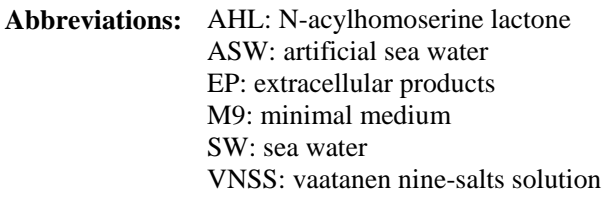

The biofouling of surfaces submerged in the marine environment includes primary colonization of the substrate by microorganisms including bacteria, microalgae, and microscopic reproductive propagules of macroorganisms such as algal zoospores. The present study reports the evaluation of the inhibitory potential of biofilms and extracellular products (EP) of the indigenous bacterium Alteromonas sp strain Ni1-LEM on the settlement of marine biofouling such as: (i) eight marine benthic diatoms and (ii) zoospores of the alga Ulva lactuca, as well as the germination of these zoospores and was compared with reference strains with proven antifouling properties, Halomonas marina (ATCC 25374) and Pseudoalteromonas tunicata. Highest antifouling activity was found for the indigenous strain. In attempts to better define the chemical nature of the antifouling substance in the EP of the Alteromonas sp strain Ni1-LEM, the culture filtrates were tested for activity after heat treatment, enzymatic treatments, dialysis through semipermeable membranes, and separation into polar (aqueous) and non-polar (organic) fractions. The results suggested that the antifouling substance in the culture filtrates to be protein or peptide in nature, thermostable, hydrophilic, and equal to or greater than 3500 daltons in molecular size. Antifouling substances from bacteria may lead to the development of novel antifouling agents in the future.

Living and inert surfaces immersed in the marine environment are usually rapidly colonized by microorganisms, the first step of which includes attachment of bacteria, diatoms, fungi, and protozoans. These are often

*Corresponding author 
Table 1. The effect of bacterial biofilms of $P$. tunicata $(\mathrm{Pt}), \boldsymbol{H}$. marina $(\mathrm{Hm})$, Alteromonas sp strain Ni1-LEM and Halomonas sp strain NC1-LEM on the settlement of common biofouling diatoms and the settlement and germination of the zoospores of the macroalga $U$. lactuca. Values presented are mean percentages of settlement from three replicate trials \pm one standard deviation.

\begin{tabular}{|l|c|c|c|c|c|}
\hline \multicolumn{1}{|c|}{ Microorganisms } & \multicolumn{5}{|c|}{ Treatments } \\
\hline Diatoms (Bacillariophyta) & Control & Pt & Hm & Ni1-LEM & Nc1-LEM \\
\hline Nitzschia sp1 & $95.4 \pm 1,7^{\mathrm{a}}$ & $52.4 \pm 5,5^{\mathrm{b}}$ & $59.5 \pm 7.8^{\mathrm{b}}$ & $41.5 \pm 3.9^{\mathrm{c}_{*}}$ & $94.0 \pm 5.7^{\mathrm{a}}$ \\
\hline Amphora sp & $100 \pm 0^{\mathrm{a}}$ & $43.4 \pm 4.3^{\mathrm{b}}$ & $52.0 \pm 0.0^{\mathrm{b}}$ & $36.8 \pm 7.1^{\mathrm{c}_{*}}$ & $100 \pm 3.0^{\mathrm{a}}$ \\
\hline Cylindrotheca closterium & $81.6 \pm 2.9^{\mathrm{a}}$ & $38.4 \pm 1,9^{\mathrm{c}}$ & $48.5 \pm 2.2^{\mathrm{b}}$ & $36.5 \pm 5.5^{\mathrm{c}_{*}}$ & $80.2 \pm 6.3^{\mathrm{a}}$ \\
\hline Nitzschia ovalis arnott & $70.9 \pm 6.8^{\mathrm{a}}$ & $27.9 \pm 6.3^{\mathrm{c}}$ & $34.2 \pm 3.4^{\mathrm{b}}$ & $24.4 \pm 2.4^{\mathrm{c}_{*}}$ & $68.3 \pm 4.2^{\mathrm{a}}$ \\
\hline Chaetoceros minutissimus & $71.5 \pm 2.5^{\mathrm{a}}$ & $25.9 \pm 4.0^{\mathrm{c}}$ & $36.4 \pm 1.7^{\mathrm{b}}$ & $22.2 \pm 3.0^{\mathrm{c}_{*}}$ & $70.4 \pm 6.5^{\mathrm{a}}$ \\
\hline Navícula sp1 & $62.3 \pm 1.5^{\mathrm{a}}$ & $18.9 \pm 1.7^{\mathrm{c}}$ & $25.1 \pm 4.0^{\mathrm{b}}$ & $16.0 \pm 2.0^{\mathrm{c}_{*}}$ & $65.2 \pm 3.8^{\mathrm{a}}$ \\
\hline Navícula sp2 & $94.1 \pm 7.8^{\mathrm{a}}$ & $43.4 \pm 6.8^{\mathrm{c}}$ & $56.2 \pm 5.1^{\mathrm{b}}$ & $41.2 \pm 2.1^{\mathrm{c}_{*}}$ & $92.2 \pm 4.0^{\mathrm{a}}$ \\
\hline Nitzschia sp2 & $93.3 \pm 3.5^{\mathrm{a}}$ & $45.5 \pm 5.0^{\mathrm{c}}$ & $53.1 \pm 8.5^{\mathrm{b}}$ & $40.1 \pm 2.4^{\mathrm{c}_{*}}$ & $94.3 \pm 3.3^{\mathrm{a}}$ \\
\hline Algae (Chlorophyta) & $\left(83.5 \pm 9.3^{\mathrm{a}}\right.$ & $(27.6 \pm 6.6)^{\mathrm{b}}$ & $(31.5 \pm 3.8)^{\mathrm{b}}$ & $(12.4 \pm 3.3)^{\mathrm{c}_{*}}$ & $(80.4 \pm 5.0)^{\mathrm{a}}$ \\
\hline Ulva lactuca & $93.4 \pm 9.6^{\mathrm{a}}$ & $19.4 \pm 2.7^{\mathrm{b}}$ & $22.3 \pm 4.4^{\mathrm{b}}$ & $7.5 \pm 2.5^{\mathrm{c}_{*}}$ & $94.0 \pm 8.8^{\mathrm{a}}$ \\
\hline & & & & & \\
\hline
\end{tabular}

Values in ( ) represent percentage germination of $U$. lactuca zoospores.

Different superscripted letters indicate significant differences (one way ANOVA and LSD a posteriori test with $\alpha=$ 0.05 and $a>b>c$ ) of data within that row. The letter " $c^{\star}$ " indicates the highest degree of antifouling activity.

followed by the settlement of algal spores and larvae of macro invertebrates (Dobretsov and Qian, 2002). This colonization process is termed "biofouling" and results in the modification and even deterioration of structures or surfaces submerged in the sea as a result of the undesired accumulations of micro-and macrofouling organisms, mediated by a complex mix of physical, chemical, and biological phenomena (Egan et al. 2001; Callow and Callow, 2002; Gehrke and Sand. 2003). Biofouling is a complex process which can be initiated by the adsorption of inorganic and organic compounds such as polysaccharides, proteins, and peptides within a few min of submerging a clean substrate in seawater (Egan et al. 2001). This initial step is often followed by the formation of a biofilm formed of bacteria or other microorganisms (Gehrke and Sand, 2003). The bacteria are not the only organisms which can produce initial colonization; diatoms with their sticky mucopolysaccharide secretions may also be involved in early film formation, and when they are abundant can promote bio-corrosion of the surface (Callow and Callow, 2002). As the biofilm grows, adhesive exudates are released which help trap additional particles and microorganisms. Among these may be included algal spores, marine fungi, and protozoans, some of which may be attracted to the film by chemosensory processes (Davies and Williamson, 1995).

Bacteria can play an important role in controlling the growth of micro-and macroalgae. It has been reported that some bacteria in the genera Flavobacterium, Cytophaga, Alteromonas Pseudomonas and Pseudoalteromonas and their excretion products are capable of inhibiting the growth of diatoms and microalgae which are common in harmful phytoplankton blooms (Yoshinaga et al. 1997; Kato et al. 1998; Lovejoy et al. 1998; Lee et al. 2000; Burgess et al. 2003). These bacteria are capable of acting on a broad range of phytoplanktonic components, including diatoms, dinoflagellates, and some bacteria in the genera Vibrio, 
Acinobacter and Flavobacterium (Yoshinaga et al. 1997). A study carried out by Hölmstrom et al. (1996) showed the capacity for the marine bacterial strain Pseudoalteromonas tunicata for inhibiting growth of the common biofouling diatom Amphora sp. With macroalgae, effects of bacterial strains have been studied in relation to the inhibition of growth of the green alga Enteromorpha (Thomas and Allsopp, 1983). Inhibitory effects of $P$. tunicata on the germination of spores of the cosmopolitan green alga Ulva lactuca and the red alga Polysiphonia sp. (a common biofouling alga) have been reported by Hölmstrom et al. (1998) and Egan et al. (2001). Also, Burgess et al. (2003) reported that Pseudomonas sp strain no. NUDMB50-11 showed excellent inhibitory activity on the germination of the spores of $U$. lactuca.

The objective of the present study was to determine the antifouling activity of the biofilms and extracellular products (EP) of the recently isolated bacterial strain Alteromonas strain Ni1-LEM from a coastal substrate in northern Chile on: (i) marine benthic diatoms, and (ii) algal zoospores from $U$. lactuca, and to compare it with reference strains with proven antifouling properties, $P$. tunicata and Halomonas marina (ATCC 25374). Alteromonas sp strain Ni1-LEM is a previously bacterium isolated at the Microbial Ecology Laboratory of the Marine Resources Faculty, Universidad de Antofagasta, Chile. The strain had shown inhibitory effects on the settlement of some marine planktonic and benthonic species in preliminary laboratory test (Ayala et al. 2006; Zapata et al. 2007).

\section{MATERIALS AND METHODS}

\section{Bacterial strains}

Evaluation was made of direct bacterial inhibition of settlement of benthic diatoms common in the microfouling community of northern Chile, as well as of the settlement and germination of spores of the cosmopolitan green macroalgae Ulva lactuca Linnaeus. Bacterial strains used to evaluate the inhibition as outlined above included a strain

Table 2. Effects of extracellular bacterial supernatants of strains of $P$. tunicata (Pt), $H$. marina (Hm), Alteromonas sp strain Ni1LEM and Halomonas sp strain Nc1-LEM on the settlement of common biofouling diatoms and the settlement and germination of zoospores of the macroalga $U$. lactuca. The values presented are mean percentages of settlement in three replicate trials \pm one standard deviation.

\begin{tabular}{|l|c|c|c|c|c|c|}
\hline \multicolumn{1}{|c|}{ Microorganisms } & \multicolumn{5}{|c|}{ Treatments } \\
\hline Diatoms (Bacillariophyta) & Ct SW & Ct M9 & Pt & Hm & Ni1-LEM & Nc1-LEM \\
\hline Nitzschia sp1 & $99.7 \pm 8.0^{\mathrm{a}}$ & $95.3 \pm 12.3^{\mathrm{a}}$ & $8.2 \pm 0.5^{\mathrm{c}}$ & $18.8 \pm 1.3^{\mathrm{b}}$ & $6.4 \pm 1.9^{\mathrm{c} *}$ & $97.2 \pm 4.6^{\mathrm{a}}$ \\
\hline Amphora sp & $99.3 \pm 6.4^{\mathrm{a}}$ & $97.0 \pm 8.9^{\mathrm{a}}$ & $9.0 \pm 1.0^{\mathrm{c}}$ & $21.2 \pm 3.5^{\mathrm{b}}$ & $7.1 \pm 0.5^{\mathrm{c} *}$ & $95.2 \pm 6.2^{\mathrm{a}}$ \\
\hline Cylindrotheca closterium & $100.0 \pm 5.7^{\mathrm{a}}$ & $97.9 \pm 19.0^{\mathrm{a}}$ & $12.2 \pm 2.0^{\mathrm{c}}$ & $8.6 \pm 5.5^{\mathrm{c}}$ & $8.0 \pm 2.2^{\mathrm{c} *}$ & $95.0 \pm 3.0^{\mathrm{a}}$ \\
\hline Nitzschia ovalis arnott & $100.0 \pm 9.2^{\mathrm{a}}$ & $98.3 \pm 6.3^{\mathrm{a}}$ & $11.1 \pm 2.0^{\mathrm{c}}$ & $12.9 \pm 3.8^{\mathrm{c}}$ & $7.8 \pm 1.5^{\mathrm{c} *}$ & $96.6 \pm 7.0^{\mathrm{a}}$ \\
\hline Chaetoceros minutissimus & $100.0 \pm 7.5^{\mathrm{a}}$ & $96.5 \pm 14.9^{\mathrm{a}}$ & $8.9 \pm 1.2^{\mathrm{c}}$ & $7.3 \pm 2.1^{\mathrm{c}}$ & $5.2 \pm 3.0^{\mathrm{c} *}$ & $95.0 \pm 10.0^{\mathrm{a}}$ \\
\hline Navícula sp1 & $96.6 \pm 8.9^{\mathrm{a}}$ & $97.3 \pm 15.0^{\mathrm{a}}$ & $6.2 \pm 4.0^{\mathrm{c}}$ & $10.3 \pm 4.0^{\mathrm{c}}$ & $7.0 \pm 6.5^{\mathrm{c} *}$ & $92.9 \pm 6.6^{\mathrm{a}}$ \\
\hline Navícula sp2 & $98.3 \pm 6.4^{\mathrm{a}}$ & $89.9 \pm 9.3^{\mathrm{a}}$ & $8.6 \pm 5.0^{\mathrm{c}}$ & $11.6 \pm 1.6^{\mathrm{c}}$ & $8.2 \pm 2.0^{\mathrm{c} *}$ & $93.6 \pm 5.0^{\mathrm{a}}$ \\
\hline Nitzschia sp2 & $100.0 \pm 15.5^{\mathrm{a}}$ & $93.9 \pm 7.0^{\mathrm{a}}$ & $9.2 \pm 1.5^{\mathrm{c}}$ & $10.4 \pm 1.4^{\mathrm{c}}$ & $7.7 \pm 3.3^{\mathrm{c} *}$ & $95.4 \pm 8.8^{\mathrm{a}}$ \\
\hline Algae (Chlorophyta) & $(80.5 \pm 9.1)^{\mathrm{a}}$ & $(78.9 \pm 6.9)^{\mathrm{a}}$ & $(2.3 \pm 0.8)^{\mathrm{c}}$ & $(27.6 \pm 3.3)^{\mathrm{b}}$ & $(1.1 \pm 0.2)^{\mathrm{c} *}$ & $97.9 \pm 9.3^{\mathrm{a}}$ \\
\hline
\end{tabular}

The values in ( ) represent percentage of germination of zoospores of $U$. lactuca.

Different superscripted letters indicate significant differences (one way ANOVA and LSD a posteriori test with $\alpha=0.05$ and $a>b>c$ ) of data within that row. The letter " $\mathrm{c}^{\star}$ " indicates the highest degree of antifouling activity. 
of Alteromonas sp (clone Ni1-LEM) first isolated by us in northern Chile from a natural substrate (red macroalgae; Rhodymenia sp), found to have anti-settlement activity against larvae of the tunicates Ciona intestinalis and Pyura praeputialis (Zapata et al. 2007). Two "reference" strains of bacteria, including Pseudoalteromonas tunicata and Halomonas marina (ATCC 25374) were tested in comparison with the Ni1-LEM strain, as these strains had been previously been reported as having activity against macrofouling (Hölmstrom et al. 1998; Maki et al. 2000). A strain of bacteria, Halomonas sp strain Nc1-LEM was employed as a negative "control" species as no antifouling activity has been shown for this strain.

All the strains had previously been cultured in Vaatanen Nine-Salts Solution (VNSS, Holmstrom et al. 1998) and had been stored in our microbial strain collection in 30\% (v/v) glycerol-seawater at $-80^{\circ} \mathrm{C}$.

\section{Diatom strains}

Pieces of polystyrene $1 \mathrm{~cm}^{2}$ in area which we had submerged in coastal seawater in for $14 \mathrm{~d}$ at $10 \mathrm{mt}$ of depth to accumulate biofilm were returned to the laboratory and repeatedly rinsed in sterile seawater so as to remove loosely attached microorganisms from the surfaces. The substrates were then each immersed in a test tubes containing with 10 $\mathrm{ml}$ of sterile marine saline solution (SSM), and the tightly adhered microorganisms were detached from the surfaces by a $30 \mathrm{sec}$ sonication of the tubes in a Cole Parmer model CPX 130 ultrasonic processor. Aliquots of 0.1 and $1.0 \mathrm{ml}$ recovered from 10 samples were individually inoculated into $250 \mathrm{ml}$ erlenmeyer flasks containing $100 \mathrm{ml}$ of Guillard (1975) f/2 algae culture medium, and incubated for two weeks at $20^{\circ} \mathrm{C}$ at a light intensity of $100 \mu \mathrm{mol} \mathrm{m} \mathrm{m}^{-2} \cdot \mathrm{s}^{-1}$ with a photoperiod of 12:12 L:D. Following the incubation, the diatom species present were isolated using the methods described by Alveal et al. (1995). Eight strains of dominant diatoms were ultimately obtained from the biofilms, including Amphora sp; Nitzschia sp1; Nitzschia sp2; Nitzschia ovalis (Arnott ex Grunow in Cleve \& Grunow, 1880); Chaetoceros minutissimus (Makarova et ProshkinaLavrenko, 1964); Cylindrotheca closterium (Enrenberg, 1841); Navícula sp1 and Navícula sp2. Axenic cultures of these diatoms were obtained by treating them with antibiotics to eliminate accompanying bacteria. The axenicity was verified by realizing the epifluorecent technique.

\section{Obtaining algal zoospores}

The methods of Egan et al. (2001) were used to obtain algal zoospores of $U$. lactuca. Samples of mature U. lactuca Linnaeus were collected from the intertidal zone on the coast at San Jorge Bay, Antofagasta, Chile, prior to sporulation as determined by microscopic examination. The thalli were cleaned of sediment and debris, and then abundantly rinsed with $0.45 \mu \mathrm{m}$ filtered, autoclaved seawater. The algal thalli were air dried at ambient temperature and ambient light for two hrs. Pieces of algae bearing sporangia were deposited in $200 \mathrm{ml}$ beakers with $100 \mathrm{ml}$ of the sterilized, filtered seawater (as above) and left exposed to light from a 60 watt (daylight) lamp.

The zoospores released were collected and deposited on one side of a $10 \mathrm{~cm}$ watch glass in $0.20 \mu \mathrm{m}$ filtered, autoclaved seawater away from the light source. After 5 to $10 \mathrm{~min}$, the spores which had migrated toward the brighter side of the watch glass were collected by pipetting and the procedure was repeated to assure the spores had migrated away from any associated microorganisms. The zoospores were then collected and immersed in $10 \mathrm{ml}$ of the $0.20 \mu \mathrm{m}$ filtered, autoclaved seawater, and the numbers per $\mathrm{ml}$ were determined using a Neubauer counting chamber.

\section{Preparation of bacterial biofilms}

The methods of Maki et al. (2000) were used to determine the effects of Alteromonas sp. Strain Ni1-LEM, Pseudoalteromonas tunicata and Halomonas marina (positive control) and Halomonas sp strain Nc1-LEM (negative control) for their comparative ability inhibit diatom microfouling. Overnight cultures of the three bacteria were grown in VNSS were centrifuged at 11000 rpm for $15 \mathrm{~min}$. The supernatant was discarded and the pellet was washed and resuspended in artificial sea water (ASW), homogenized, and recentrifuged. The pellet was resuspended in 1/10 ml VNSS broth (Hölmstrom et al. 1998), and homogenized. Direct counts of the bacteria were made using the DAPI epifluorescence technique. Nuclon ${ }^{\circledR}$ multiwellpolystyrene chambers $(8 \times 12$ wells; $6 \mathrm{~mm}$ diameter) each received $200 \mu$ lt of $1 / 10$ VNSS per well, and were then inoculated with a bacterial suspension containing $10^{8}$ cells $\cdot \mathrm{ml}^{-1}$, and were incubated at $20^{\circ} \mathrm{C}$ for $48 \mathrm{hrs}$. in one room with controlled temperature. Following incubation, the culture medium was removed from each treatment, followed by repeated rinsing with ASW to eliminate bacteria not firmly adherent to the substrate. The numbers of firmly adherent bacteria were determined by direct counts in the microscope. All the wells then received $200 \mu \mathrm{l}$ of sterile seawater prior to making the bioassays with diatoms and algal zoospores.

\section{Evaluation of the effects of bacterial biofilms on settlement of diatoms and algal zoospores}

Once the bacterial biofilms were obtained, the multiwell chambers, containing $200 \mu \mathrm{lt}$ of $0.2 \mu \mathrm{m}$ filtered seawater were inoculated separately with the individual diatoms at concentrations of about $3,5 \cdot 10^{5}$ cells $\cdot \mathrm{ml}^{-1}$. Control plates were established which either did not contain bacterial films, or contained bacterial films prepared with the negative control (Halomonas sp strain Nc1-LEM). Experimental and control chambers were run in triplicate, for periods of $24 \mathrm{hrs}$. Following this exposure period, counts of settled diatoms were made using an Olympus 
model IX50 inverted microscope at 100X. The results were expressed in percentage adherence of each diatom.

In tests for settlement and germination of $U$. lactuca, each well of a test chamber received $200 \mu \mathrm{l}$ of zoospores suspension containing a total of about 2800 spores. The plates were incubated at ambient temperature $\left(24 \pm 4^{\circ} \mathrm{C}\right)$ for 2 hrs in total darkness to allow settlement of the zoospores. Following incubation, the plates were washed with ASW five times to eliminate zoospores not firmly adherent to the substrate. The plates were then examined in the inverted microscope at $100 \mathrm{X}$ to count the numbers of zoospores which had firmly settled. In a second group having the same treatment, incubation was carried on for three days at ambient temperature with results observed and quantified as done with the first group. Tests with the U. lactuca zoospores were also carried out in triplicate for each type of bacterial film tested.

$\%$ germination $=\frac{N^{0} \text { of zoospores germinated }}{N^{0} \text { of zoospores settled }} \times 100$

\section{Obtaining bacterial EP in culture supernatants}

EP were obtained from $1 \mathrm{lt}$ cultures of the three bacterial strains tested by growing each to the stationary phase in M9 broth (minimal medium) with constant stirring at a room temperature of about $20^{\circ} \mathrm{C}$. The cultures were centrifuged at $11000 \mathrm{rpm}$ for $15 \mathrm{~min}$ at $4^{\circ} \mathrm{C}$, and the supernatant was filtered twice through $0.2 \mu \mathrm{m}$ Millipore ${ }^{\circledR}$ filters and stored at $-20^{\circ} \mathrm{C}$ for subsequent use in the fouling inhibition bioassays. The axenic condition of the bacterial EP was verified using microscopic epifluorescence techniques.

\section{Enzymatic treatment the EP}

In order to determine if the substance active in inhibition against diatoms and algal spores was protein or peptidelike, the EP were treated with the enzymes pronase E, and carboxypeptidase $\mathrm{G}$, at a final concentration of $200 \mu \mathrm{g} \mathrm{ml}^{-1}$. The mixtures were incubated at $37^{\circ} \mathrm{C}$ for two hrs (pronase E) and at $30^{\circ} \mathrm{C}$ for $3 \mathrm{hrs}$ (carboxypeptidase G), both at $\mathrm{pH}$ 7.1. Subsequently both solutions of the enzyme-treated EP were separately submitted to heating in an $80^{\circ} \mathrm{C}$ water bath for $20 \mathrm{~min}$ to denature all protein and enzymic activity. Controls were prepared for both enzymic treatments using $0.45 \mu \mathrm{m}$ filtered, sterile seawater at the same concentrations as in the test systems with EP, as well as normal seawater and the EP without enzymic treatment in M9 medium.

\section{Heat treatment of the EP}

In order to determine if the substance inhibitory to diatoms and algal spores is affected by heating, $10 \mathrm{ml}$ samples of EP were treated at $80^{\circ} \mathrm{C}$ for $30 \mathrm{~min}$ in a water bath, followed by cooling to room temperature, these samples were filtered to
$0.2 \mu \mathrm{m}$. The treated and untreated EP were then tested to determine their comparative inhibitory effects on the diatoms and $U$. lactuca zoospores.

\section{Obtaining a dialyzed fraction of EP}

To determine the approximate molecular size of the inhibitory substance, $100 \mathrm{ml}$ of the EP were dialized for 12 hrs at $4^{\circ} \mathrm{C}$ against $0.2 \mu \mathrm{m}$ filtered sterile distilled water. Benzoilated membranes were used, having cutoffs of either 3500 or 10000 daltons (Sigma $\left.{ }^{\circledR}\right)$. Each dialysate was stored under sterile conditions at $-20^{\circ} \mathrm{C}$ until it was employed in bioassays on diatoms and $U$. lactuca zoospores.

\section{Obtaining organic extracts of the EP}

Samples of $250 \mathrm{ml}$ of the EP were extracted with $100 \mathrm{ml}$ of dichloromethane, separating the organic (nonpolar) phase from the aqueous (polar) phase. The solvent was removed from the organic fraction by vacuum evaporation in a Bûchi rotary evaporator at $40^{\circ} \mathrm{C}$. The organic extracts were redissolved in ethanol to a concentration of $9-10 \mathrm{mg} \mathrm{ml}^{-1}$. Both the polar and non-polar fractions were used in bioassays testing for inhibitory properties on diatoms and U. lactuca zoospores.

\section{Evaluating the effects of the EP on the settlement of diatoms and algal zoospores}

Multiwell polystyrene chambers (as above) were used for this testing in a manner similar to that described above for the living bacterial films. In the present testing, each wells received $0.1 \mathrm{ml}$ of diatom culture which was in the prestationary growth phase, and had been rinsed with ASW to eliminate any effects of the algae culture medium ( $\mathrm{F} / 2$; Guillard, 1975); $0.1 \mathrm{ml}$ of EP from the different treatments as described above in this section were added to the wells on the plates, giving test diatom concentrations of about 3,5 $10^{5}$ cell $\mathrm{mL}^{-1}\left(2,510^{5}\right.$ cells $\left.\mathrm{cm}^{-2}\right)$. The plates were incubated at $20^{\circ} \mathrm{C}$ in a controlled temperature incubator at $20^{\circ} \mathrm{C}$, with a 12L:12D photoperiod at $100 \mu \mathrm{mol} \mathrm{m}{ }^{-2} \cdot \mathrm{s}^{-1}$. Diatom counts were made after 24 hrs of incubation, after rinsing each chamber five times with ASW to remove any non-adherent cells, and then observed in the inverted microscope. Counts of the adherent diatoms were made for each experimental arrangement, with the results expressed as cells present per $\mathrm{cm}^{2}$.

In tests with $U$. lactuca zoospores, about 2800 spores in $100 \mu \mathrm{l}$ of sterile seawater were added to each well, followed by $100 \mu \mathrm{L}$ of EP for each type of treatment. The preparations were incubated at a room temperature of about $20^{\circ} \mathrm{C}$ in total darkness for two hrs to allow zoospore settlement. Following incubation, the plates were washed with ASW five times to eliminate zoospores not firmly adherent to the substrate. The plates were then examined in the inverted microscope at $100 \mathrm{X}$ to count the numbers of zoospores which had firmly settled. The plates were then allowed to incubate in ambient light for 10-15 hrs, and then 
observed using the inverted microscope to observe for any germination of the spores. When it was confirmed that no germination had occurred, the seawater was removed from the wells and counts were made of the attached spores. A second, identical set of preparations was run to test the effects of the EP on germination of $U$. lactuca zoospores. In these tests, after the spores had settled and were counted, the seawater which had been removed was replaced with an equal volume of seawater containing the EP from the various treatments as described above. These systems were

Table 3. Preliminary characterization of extracellular bacterial supernatants from $P$. tunicata (Pt). $H$. marina (Hm) and Alteromonas sp (Ni1-LEM) on the settlement of the common biofouling diatoms Nitzschia sp1 (Nc), Amphora sp (Amp), Cylindrotheca closterium (Cc), Nitzschia ovalis arnott (Fp), Chaetoceros minutissimus (Nm), Navicula sp1 (Nav sp1), Navicula sp2 (Nav sp2) and Nitzschia sp2 (Nitz sp2) and in the settlement and germination of the spores of $U$. lactuca. The letters presented are the degree of inhibition of settlement.

\begin{tabular}{|c|c|c|c|c|c|c|c|c|c|}
\hline \multirow[t]{2}{*}{ Treatments } & \multicolumn{9}{|c|}{ Microorganisms } \\
\hline & Nc & Amp & Cc & $F p$ & $\mathrm{Nm}$ & Nav sp1 & Nav sp2 & Nitz sp1 & U. lactuca \\
\hline \multicolumn{10}{|l|}{ Enzymic } \\
\hline Pt + Prot & $A$ & $A$ & $A$ & $A$ & $A$ & A & $A$ & $A$ & $A(A)$ \\
\hline Pt + Pept & $A$ & $A$ & $A$ & $A$ & $A$ & $A$ & $A$ & $A$ & $A(A)$ \\
\hline $\mathrm{Hm}+$ Prot & A & A & A & A & A & A & A & A & $A(A)$ \\
\hline $\mathrm{Hm}+\mathrm{Pept}$ & $A$ & $A$ & $A$ & $A$ & $A$ & $A$ & $A$ & $A$ & $A(A)$ \\
\hline Ni1-LEM + Prot & $\mathrm{C}$ & C & C & C & C & $\mathrm{C}$ & C & C & $A(A)$ \\
\hline Ni1-LEM + Pept & A & $A$ & $A$ & $A$ & A & A & $A$ & A & $A(A)$ \\
\hline \multicolumn{10}{|l|}{ Heat denatured } \\
\hline Pt $80^{\circ} \mathrm{C}$ & $A$ & $A$ & A & $A$ & A & $A$ & $A$ & A & $C(C)$ \\
\hline $\mathrm{Hm} 80^{\circ} \mathrm{C}$ & $\mathrm{C}$ & $\mathrm{C}$ & $\mathrm{C}$ & $\mathrm{C}$ & C & C & $\mathrm{C}$ & $\mathrm{C}$ & $C(C)$ \\
\hline Ni1-LEM $80^{\circ} \mathrm{C}$ & C & C & $\mathrm{C}$ & C & C & C & $\mathrm{C}$ & C & $C(C)$ \\
\hline \multicolumn{10}{|l|}{ Dyalizates } \\
\hline Pt $3500 \mathrm{Da}$ & $\mathrm{C}$ & C & C & C & C & C & C & C & $C(C)$ \\
\hline Pt $10000 \mathrm{Da}$ & $A$ & $A$ & $A$ & $A$ & $A$ & $A$ & $A$ & $A$ & $A(A)$ \\
\hline $\mathrm{Hm} 3500 \mathrm{Da}$ & B & B & B & $\mathrm{B}$ & C & B & $\mathrm{C}$ & $\mathrm{C}$ & $C(\mathrm{C})$ \\
\hline $\mathrm{Hm} 10000 \mathrm{Da}$ & C & C & B & C & C & $\mathrm{C}$ & B & $\mathrm{C}$ & $B(C)$ \\
\hline Ni1 $3500 \mathrm{Da}$ & $\mathrm{C}$ & C & $\mathrm{C}$ & C & C & C & $\mathrm{C}$ & C & $C(C)$ \\
\hline Ni1 $10000 \mathrm{Da}$ & C & $\mathrm{C}$ & $\mathrm{C}$ & C & C & C & $\mathrm{C}$ & $\mathrm{C}$ & $C(C)$ \\
\hline \multicolumn{10}{|c|}{ Organic phase (non polar) } \\
\hline $\mathrm{Pt}$ & $A$ & $A$ & $A$ & $A$ & $A$ & $A$ & $A$ & $A$ & $A(A)$ \\
\hline $\mathrm{Hm}$ & $A$ & $A$ & $A$ & $A$ & A & A & A & A & $A(A)$ \\
\hline Ni1-LEM & $A$ & $A$ & $A$ & $A$ & $A$ & $A$ & $A$ & $A$ & $A(A)$ \\
\hline \multicolumn{10}{|c|}{ Aqueous phase (polar) } \\
\hline $\mathrm{Pt}$ & $A$ & $A$ & $A$ & $A$ & $A$ & $A$ & $A$ & $A$ & $A(A)$ \\
\hline $\mathrm{Hm}$ & $\mathrm{B}$ & B & $\mathrm{B}$ & B & $A$ & $A$ & $\mathrm{~B}$ & $A$ & $\mathrm{~B}(\mathrm{~B})$ \\
\hline Ni1-LEM & $A$ & $A$ & $A$ & $A$ & $A$ & $A$ & $A$ & $A$ & $A(A)$ \\
\hline
\end{tabular}

The letters in ( ) represent the percentage germination of U. lactuca zoospores. Prot: Pronase E; Pept: Carboxypeptidase G

The level of inhibitory activity of treatments were categorize as non-inhibitory ( $A=70-100 \%$ settlement), slightly inhibitory ( $B=70-20 \%$ settlement) or strongly inhibitory $(0-20 \%$ settlement). 
incubated for three days at room temperature and ambient lighting conditions and then observed in the inverted microscope to determine the percentage of zoospore germination in each well. Germination was noted as positive when multiple cell clusters from each zoospore could be observed.All the experimental tests with diatoms and $U$. lactuca zoospores were carried out in triplicate.

\section{Statistical analyses}

The results obtained were submitted to a one-way analysis of variance (ANOVA, $\alpha=0.05$ ) to evaluate the effect of the bacterial biofilms and their EP on the inhibition of settlement of diatoms, and on the inhibition of settlement and germination of $U$. lactuca zoospores. Determination of the factors which may have produced significant differences was carried out using LSD multiple comparison test.

\section{RESULTS}

\section{Effect of bacterial biofilms on settlement of diatoms and algal zoospores}

Results of tests on the effects of bacterial biofilms on diatom settlement, and settlement and germination of $U$. lactuca zoospores are presented in Table 1. Both the strain isolated in our laboratory (Alteromonas sp clon Ni1-LEM) and the reference strains $P$. tunicata significantly $(\mathrm{P}<0.05)$ inhibited the diatoms and $U$. lactuca zoospores in comparisons with controls without biofilms, and the control prepared with films of the non-inhibitory Halomonas sp (clon Nc1-LEM).The highest degree of antifouling activity was noted with Alteromonas sp (Clon Ni1-LEM), in comparison with the reference strains.

\section{Effects of EP on the settlement of diatoms and algal zoospores}

Results obtained on the effects of EP on diatom settlement after 24 hrs incubations and on settlement and germination of $U$. lactuca zoospores are presented in Table 2. Similarly to the results obtained with the bacterial biofilms, Alteromonas sp clon Ni1-LEM and the reference strain $P$. tunicata significantly $(\mathrm{P}<0,05)$ inhibited the diatoms and $U$. lactuca zoospores in comparisons with controls done using sea water (SW), M9 and the negative control preconditioned with the biofilm produced by the inactive bacterium Halomonas sp (clon Nc1-LEM). Again, the highest degree of antifouling activity was noted with Alteromonas sp (Clon Ni1-LEM).

\section{Enzymatic treatments of EP, and their effects on inhibition of diatoms and zoospores of $U$. lactuca}

Theresults obtained on the effects of the two enzyme treatments of EP on their capacity for fouling inhibition of diatoms and algal spores are presented in Table 3 . These results showed that both the enzymes used suppressed the inhibitory activity of the reference strains $P$. tunicata and $H$. marina showing high values for settlement of the diatoms, and settlement and germination of the U. lactuca zoospores compared with results from untreated supernatants, suggesting that inhibitory proteins or peptides had been denatured by the enzymic treatments. Only the enzyme carboxypeptidase $\mathrm{G}$ affected the inhibitory activity of the Alteromonas sp clon Ni1-LEM supernatant on the diatoms in this study, suggesting that the inhibitor was peptide-like. In contrast, since the settlement and germination of $U$. lactuca spores was affected by both enzyme-treated supernates, compounds inhibitory to Ulva could have been of both protein and/or peptide nature.

\section{Heat treatment of EP and their inhibitory effects on benthic diatoms and $U$. lactuca zoospores}

The results obtained after exposure of the diatoms and algal zoospores to the $80^{\circ} \mathrm{C}$ heat-treated bacterial supernatants (Table 3) indicated that the compound active in fouling inhibition was thermoresistent, since the results after the heat treatment were the same with the EP as those obtained without the heat treatment (Table 2).

\section{Effects of dialyzed fractions of EP on diatoms and U. lactuca zoospores}

The results obtained by separation by molecular size of EP using dialysis at 3500 and 10000 daltons are shown in Table 3 and reveal that for $P$. tunicata the inhibitory fraction is found in the supernatant dialyzed at 3500 daltons, having inhibitory effects on the settlementof the eight diatomspecies, and on the germination of U. lactuca. With extracellular supernatants from $H$. marina and Alteromonas sp (clon Ni1-LEM), the results show the inhibitory effects of the 3500 and 10000 dalton fractions on the study organisms (Table 3). These results suggest that the active compound from $P$. tunicata had a size equal to or greater than 3500 and less than 10000 daltons, and greater or equal to 3500 daltons for $H$. marina and Alteromonas sp (clon Ni1-LEM).

\section{Effects of organic extracts and the aqueous phase of EP on the settlement of diatoms and zoospores of $U$. lactuca.}

The results presented in Table 3 show that only the aqueous phase of the bacterial supernatants of the three bacterial strains tested showed inhibition of settlement of the eight diatom species and settlement and germination of $U$. lactuca zoospores. This result suggested that the active component was of a polar compound.

\section{DISCUSSION}

Table 1 and Table 2 shows the significant effects of bacterial biofilms and their EP of "reference" strain of bacteria Pseudoalteromonas tunicate and Halomonas marina and native bacterium Alteromonas sp strain Ni1LEM, on inhibition of settlement of common fouling 
diatoms and settlement and germination of $U$. lactuca zoospores, with the highest activity attributable to the Alteromonas strain Ni1-LEM. Various authors have indicated that bacterial biofilms were able to inhibit the settlement of benthic diatoms (Gawne et al. 1998; Hölmstrom et al. 2000) and settlement and subsequent germination of algal zoospores (Egan et al. 2001; Patel et al. 2003). On the another hand, the antidiatoms effects of the bacterium HYK0203-SK02 Pseudomona putida were shown to be effective against the pelagic diatoms Stephanodiscus hantzschii and the cyanobacterium Microcystis aeruginosa (Kang et al. 2005). Most bacterial isolates from the alga Ulva reticulata inhibited the growth of the diatoms Nitzschia paleacea but did not cause its mortality in a study by Dobretsov and Qian (2002). These same authors attribute the effects of biofilms on surface fouling to their physical and chemical properties. These moderating factors include the strains of bacteria and diatoms involved; adhesive adaptations of the microorganisms including flagellae, pili, peduncles, feet or rafia, and the sizes and shapes of microorganisms involved (Gawne et al. 1998; Wetherbee et al. 1998; Egan et al. 2001; Pasmore and Costerton, 2003). Also of importance is the capacity of the microorganisms for the production of extracellular adhesive substances such as polysaccharides (Wustman et al. 1997) glycoproteins, and polyglycans (Lind et al. 1997). One of the most extensively studied bacteria with antifouling activity has been Pseudoalteromonas tunicata isolated directly from the surface of the tunicate Ciona intestinalis. This bacterium was shown to be able to inhibit the settlement and growth of a large number of organisms including invertebrate larvae, bacteria, diatoms, fungi, and macroalgal zoospores (Hölmstrom and Kjelleberg, 1999; Egan et al. 2000; Egan et al. 2001). Studies by Maki et al (1988) using 18 different bacterial strains, evaluated their effect on settlement of cirripeds, finding seven inhibitory species. The most active inhibitory species was Deleya marina (presently known as Halomonas marina). Subsequent studies with $H$. marina showed that this bacterium could attach to different substrates on which the cirriped larvae then showed variable settlement responses, suggesting a complex interaction between the substrate, the bacterial strain, and the larva (Maki et al. 2000). There are, however, no reports in the literature on the effects of $H$. marina on the settlement of diatoms or settlement and germination of $U$. lactuca zoospores. Moreover, previous studies have shown that biofilm of our native bacterium Alteromonas sp strain Ni1-LEM and their EP inhibits the byssal formation in the mussel Semimitylus algosus (Ayala et al. 2006) and inhibits the settlement of tunicate larvae Ciona intestinalis and Pyura praeputialis (Zapata et al. 2007). This bacteria has an extended stationary growth phase, during which it produces metabolites actively inhibitory to fouling organisms (data no show). This results are in agreement with Egan et al. (2001) and Lau and Qian, (2001), who indicated that $P$. tunicate has an extended stationary phase, in which it produces at least five extracellular components that inhibited the settlement of a broad range of fouling organisms. Stationary-phase supernatant was used because within the marine environment most bacteria spend long periods of time in stationary phase and commonly produce active secondary metabolites in this stage.

In the present study, the assays of supernatants treated with pronase E, carboxypeptidase G, organic extracts, aqueous phase extract, and heat treated extracts (Table 3) suggested that the actively inhibitory products of Alteromonas sp strain Ni1-LEM which were able to inhibit the attachment of diatoms and settlement and germination of $U$. lactuca zoospores were proteins or thermostable peptides of low molecular weight and with polar characteristics. This agrees with Holmström and Kjelleberg (1999) and Egan et al. (2001) that reported that polar, heath stable, low molecular weight peptides or proteins inhibited the settlement of bacteria, fungi, microalgae, algal zoospores, and invertebrates. Later, results from high performance liquid chromatography (HPLC) carried out on active extracellular fractions of our bacteriumshowed that the protein or peptide involved as an active inhibitory component against marine diatoms (data no shown) and tunicate larvae of $C$. intestinalis and $P$. praeputialis (Zapata et al. 2007), was not a hydrophobic protein, but was polar, and thus was easily dispersed though the marine environment. In contrast to our results in Alteromonas sp strain Ni1-LEM, Egan et al (2001) have indicated that the antialgal activities of $P$. tunicate produces an extracellular component that is heat sensitive. It is feasible that low molecular weight proteins and peptides are less affected by heat. Examples of such peptides are the heat stable enterotoxins produced by Escherichia coli (Robins-Browne, 1994). There is little published information on the nature of the inhibitory activity of Alteromonas species in the establishment of fouling communities. For instance, Kon-ya et al. (1995) identified the ubiquinona-8 molecule as responsible for the anti-larval activity shown by Alteromonas sp. KK10304 isolated from a marine sponge. 2-n-pentyl-4-quinolinol produced by the marine bacterium Alteromonas sp. inhibited the growth of plankton diatoms (Long et al. 2003).

The EP of our bacterium functioned directly as chemosensory inhibitory signals which were easily diffused throughout the aqueous medium, and could be internal components in the transmission of biochemical signals. Decho et al. (1998) suggested that these compounds represented a logical option for a functional signaling molecule in the marine environment due to its solubility in water and ease of synthesis since the biochemical machinery needed for producing specialized proteins and peptides are readily available within most organisms, and that a variety of signals could be produced depending on the lengths and peptide sequences produced. On the other hand, Tait et al. (2005) have demonstrated that bacterial Nacylhomoserine lactone (AHL) (Family of quorum sensing signalling molecules) molecules are required before there is attraction of zoospores to bacterial biofilm. Zoospores are attracted to biofilms of the wild type Vibrio anguillarum 
but not to mutants that do not produce AHLs. They have demonstrated that attraction is disrupted with recombinant $V$. anguillarum producing AiiA (autoinducer inactivation) proteins. This protein, discovered by Dong et al (2000) in an Bacillus isolate enzymatically inactivates AHLs by hydrolysing the homoserine lactone ring. Presumably in case of our bacterium, the protein or peptide of the EP would be the cause of the loss of AHL synthesis and as consequence, the inhibition of the settlement of diatoms and $U$. lactuca zoospores. Certainly bacterial antialgal activity in general deserves further studies.

At the moment, the mechanism by which Alteromonas sp strain Ni1-LEM inhibits the settlement of components of biofouling, are not known. Nevertheless, Lovejoy et al. (1998), suggested that bacteria inhibitory to algal growth acted by means of two mechanisms, one direct and one indirect; an example of the first mechanism is that in Cytophaga sp. (strain J18/M01) which induces lysis in diatom cultures beginning after two hrs of exposure to living bacteria, but not by EP of the same bacterial strain (Imai et al. 1993). Indirect attacks effect inhibition of algae through emission from the bacteria of chemical products or extracellular exudates. Lovejoy et al. (1998) evaluated the effects of strains of Pseudoalteromonas spisolated from the Huon Estuary, Tasmania (Australia) on the growth of the red-tide dinoflagellates Gymnodinium catenarum, Chatonella marina and Heterosigma akashiwo,finding that the presence of the marine bacteria produced adverse effects on the three dinoflagellates. The deleterious effects were related to the production of high molecular weight extracellular substances by the bacteria. In addition, the bacterium, Pseudoalteromonas sp A28 was demonstrated to lyse marine algae via the production of extracellular proteases (Lee et al. 2000). Egan et al. (2001) reported that the antialgal substance as cited in the preceding affected the cell membrane of zoospores of $U$. lactuca, inhibiting their settlement and germination. This was attributed to the fact that the plasma of the membrane was exposed prior to settlement; although once the zoospore settled it formed a protective cell wall. A second mechanism proposed to explain the inhibitory effect of the active component produced by the bacteria was that the component functioned as a negative biochemical signal for settlement and germination, preventing their attachment and ultimately resulting in their death (Egan et al. 2001).

The preceding discussion implies the feasibility of developing bacterial biofilms on natural marine substrates, and that the EP of these biofilms could function in inhibition of settlement of microalgae and macroalgae components of fouling communities. The results shown in this study are important for future research into the biology, ecology, microbiology and marine botany which attempts to elucidate biological interactions which occur among different organisms associated with surfaces in the marine environment, and with the identification of natural metabolites which could in the future lead to the development of applied methods for the mitigation of economically important marine fouling.

\section{REFERENCES}

ALVEAL, K.; FERRARIO, M.; OLIVEIRA, E. and SAR, E. Manual de Métodos Ficológicos. Editorial Anibal Pinto S.A., Concepción, Chile, 1995, p. 863.

AYALA, Cristina; CLARKE, Marcela and RIQUELME, Carlos. Inhibition of byssal formation in Semimytilus algosus (Gould, 1850) by a film-forming bacterium isolated from biofouled substrata in northern Chile. Biofouling, 2006, vol. 22, no. 1, p. 61-68.

BURGESS, J. Grant; BOYD, Kenneth G.; ARMSTRONG, Evelyn; JIANG, Zhong; YAN, Liming; BERGGREN, Matz; MAY, Ulrika; PISACANE, Tony; GRANMO, Ake and ADAMS, David R. The development of a marine natural product-based antifouling paint. Biofouling, 2003, vol. 19, no. 1, p. 197-205.

CALLOW, Maureen E. and CALLOW, James A. Marine biofouling: a sticky problem. Biologist, 2002, vol. 49, no. 1, p. 1-5.

DAVIES, A. and WILLIAMSON, P. Marine Biofouling: A sticky problem. NERC News, April 1995, Marine BioFoulNet.

DECHO, Alan W.; BROWNE, Kenneth and ZIMMERFAUST, Richard K. Chemical cues: why basic peptides are signal molecules in marine environments. Limnology and Oceanography, November 1998, vol. 43, no. 7, p. 14101417.

DOBRETSOV, Sergey V. and QIAN, Pei-Yuan. Effect of bacteria associated with the green alga Ulva reticulata on marine micro-and macrofouling. Biofouling, January 2002, vol. 18, no. 3, p. 217-228.

DONG, Yi-Hu; XU, Jin-Ling; LI, Xian-Zhen and ZHANG, Lian-Hui. AiiA, an enzyme that inactivates the acylhomoserine lactone quorum sensing signal and attenuates the virulence of Erwinia carotovora. Proceedings of the National Academy of Sciences of the United States of America, March 2000, vol. 97, no. 7, p. 3526-3531.

EGAN, Suhelen; THOMAS, Torsten; HOLMSTRÖM, Carola and KJELLEBERG, Staffan. Phylogenetic relationship and antifouling activity of bacterial epiphytes from the marine algae Ulva lactuca. Environmental Microbiology, June 2000, vol. 2, no. 3, p. 343-347.

EGAN, Suhelen; JAMES, Sally; HOLMSTRÖM, Carola and KJELLEBERG, Staffan. Inhibition of algal spore germination by the marine bacterium Pseudoalteromonas 
tunicata. FEMS Microbiology Ecology, March 2001, vol. 35, no. 1, p. 67-73.

GAWNE, Benjamin; WANG, Yan; HOAGLAND, Kyle D. and GRETZ, Michael R. Role of bacterial and bacterial exopolymer in the attachment of Achnanthes longipes (bacillariophyceae). Biofouling, 1998, vol. 13, no. 2, p. 137156.

GEHRKE, T. and SAND, W. Interactions between microorganisms and physicochemical factors cause MIC of steel pilings in harbours (ALWC). NACE International Corrosion, 2003, p. 1-8.

GUILLARD, R. Culture of phytoplankton for feeling marine invertebrates. Plenum Press, New York, USA, 1975. p. 29.

HOLMSTROM, Carola; JAMES, Sally; EGAN, Suhelen and KJELLEBERG, Staffan. Inhibition of common fouling organisms by marine bacterial isolates with special reference to the role of pigmented bacteria. Biofouling, 1996, vol. 10, no. 1-3, p. 251-259.

HOLMSTROM, Carola; JAMES, Sally; NEILAN, Brett A.; WHITE, David C. and KJELLEBERG, Staffan. Pseudoalteromonas tunicata sp nov., a bacterium that produces antifouling agents. International Journal of Systematic Bacteriology, October 1998, vol. 48, no. 4, p. 1205-1212.

HOLMSTROM, Carola and KJELLEBERG, Staffan. Marine Pseudoalteromonas species are associated with higher organisms and produce biologically active extracellular agents. FEMS Microbiology Ecology, December 1999, vol. 30, no. 4, p. 285-293.

HOLMSTROM, C.; STEINBERG, P.; CHRISTOV, V. and KJELLEBERG, S. Bacteria immobilized in hydrogels: a novel concept to prevent development of biofouling communities. Biofouling, 2000, vol. 15, no. 1-3, p. 109117.

IMAI, I.; ISHIDA, Y. and HATA, Y. Killing of marine phytoplankton by a gliding bacterium Cytophaga sp., isolated from the coastal sea of Japan. Marine Biology, August 1993, vol. 116, no. 4, p. 527-532.

KANG, Y-H.; KIM, J.-D.; KIM, B.-H.; KONG, D.-S. and HAN, M.-S. Isolation and characterization of a bio-agent antagonistic to the diatom, Stephanodiscus hantzschii. Journal of Applied Microbiology, May 2005, vol. 98, no. 5, p. $1030-1038$.

KATO, Junichi; AMIE, Junya; MURATA, Yoshinori; KURODA, Akio; MITSUTANI, Atsushi and OHTAKE, Hisao. Development of a genetic transformation system for an alga-lysing bacterium. Applied and Environmental Microbiology, June 1998, vol. 64, no. 6, p. 2061-2064.
KON-YA, K.; SHIMIDZU, N.; OTAKI, N.; YOKOYAMA, A.; ADACHI, K. and MIKI, W. Inhibitory effect of bacterial ubiquinones on the settling of barnacles, Balanus amphitrite. Cellular and Molecular Life Sciences, February 1995, vol. 51, no. 2, p. 153-155.

LAU, S.C.K. and QIAN, P.-Y. Larval settlement in the serpulid polychaete Hydroides elegans (Haswell) in response to bacterial film: an investigation of the nature of putative larval settlement cue. Marine Biology, February 2001, vol. 138, no. 2, p. 321-328.

LEE, Sun-Og; KATO, Junichi; TAKIGUCHI, Noboru; KURODA, Akio; IKEDA, Tsukasa; MITSUTANI, Atsushi and OHTAKE, Hisao. Involvement of an extracellular protease in algicidal activity of the marine bacterium Pseudoalteromonas sp strain A28. Applied and Environmental Microbiology, October 2000, vol. 66, no. 10, p. 4334-4339.

LIND, Jan; HEIMANN, Kirsten; MILLER, Elizabeth; VAN VLIET, Catherine; HOOGENRAAD, Nicholas J. and WETHERBEE, Richard. Substratum adhesion and gliding in a diatom are mediated by extracellular proteoglycans. Planta, September 1997, vol. 203, no. 2, p. 213-221.

LONG, Richard A.; QURESHI, Asfia; FAULKNER, D. John and AZAM, Farooq. 2-n-pentyl-4-quinolinol produced by a marine Alteromonas sp. and its potential ecological and biogeochemical roles. Applied and Environmental Microbiology, January 2003, vol. 69, no. 1, p. 568-576.

LOVEJOY, Connie; BOWMAN, John and HALLEGRAEF, Gustaaf. Algicidal effects of a novel marine Pseudoalteromonas isolate (class Proteobacteria, gamma sub-division) on harmful algal bloom species of the genera Chattonella, Gymnodinium, and Heterosigma. Applied and Environmental Microbiology, August 1998, vol. 64, no. 8, p. 2806-2813.

MAKI, J.S.; RITTSCHOF, D.; COSTLOW, J.D. and MITCHELL, R. Inhibition of attachment of larval barnacles, Balanus amphitrite, by bacterial surface films. Marine Biology, February 1988, vol. 97, no. 2, p. 199-206.

MAKI, J.S.; DING, L.; STOKES, J.; KAVOURAS, J.H. and RITTSCHOF, D. Substratum/ bacterial interaction and larval attachment: Films an exopolysaccharides of Halomonas marina (ATCC 25374) and their effects on barnacle cyprid larvae, Balanus amphitrite Darwin. Biofouling, 2000, vol. 16, no. 2-4, p. 159-170.

PASMORE, Mark and COSTERTON, J. William. Biofilms, bacterial signaling, and their ties to marine biology. Journal of Industrial Microbiology and Biotechnology, July 2003, vol. 30, no. 7, p. 407-413.

PATEL, Pratixa; CALLOW, Maureen E.; JOINT, Ian and CALLOW, James A. Specificity in the settlement- 
modifying response of bacterial biofilms towards zoospores of the marine alga Enteromorpha. Environmental Microbiology, May 2003, vol. 5, no. 5, p. 338-349.

ROBINS-BROWNE, R. Escherichia coli strains that cause diahorroea: models of bacterial pathogenesis. In: GILBERT, G.L. ed. Recents Advances in Microbiology. Melbourne, The Autralian Society for Microbiology Inc., 1994, p. 292-375.

TAIT, Karen; JOINT, Ian; DAIKYN, Mavis; MILTON, Debra L.; WILLIAMS, Paul and CAMARA, Miguel. Disruption of quorum sensing in seawater abolishes attraction of zoospores of the green alga Ulva to bacterial biofilms. Environmental Microbiology, February 2005, vol. 7, no. 2, p. 229-240.

THOMAS, R.W.S.P. and ALLSOPP, D. The effects of certain periphytic marine bacteria upon the settlement and growth of Enteromorpha, a fouling alga. Biodeterioration, 1983, vol. 5, p. 348-357.

WETHERBEE, Richard; LIND, Jan L.; BURKE, Jo and QUATRANO, Ralph S. The first kiss: establishment and control of initial adhesion by raphids diatoms - Minireview. Journal of Phycology, February 1998, vol. 34, no. 1, p. 915.

WUSTMAN, Brandon A.; GRETZ, Michael R. and HOAGLAND, Kyle D. Extracellular matrix assembly in diatoms (Bacillariophyceae): I. A model of adhesives based on chemical characterization and localization of polysaccharides from the marine diatom Achnantes longipes and other diatoms. Plant Physiology, April 1997, vol. 113, no. 4, p. 1059-1069.

YOSHINAGA, I.; KAWAI, T. and ISHIDA, Y. Analysis of algicidal ranges of the bacteria killing the marine dinoflagellate Gymnodinium mikimotoi isolated from Tanabe Bay, Wakayama Pref., Japan. Fisheries Science, February 1997, vol. 63, no. 1, p. 94-98.

ZAPATA, Manuel; SILVA, Fernando; LUZA, Yery; WILKENS, Marcela and RIQUELME, Carlos. The inhibitory effect of biofilms produced by wild bacterial isolates to the larval settlement of the fouling ascidia Ciona instestinalis and Pyura praeputialis. Electronic Journal of Biotechnology [online]. 15 January 2007, vol. 10, no. 1. Available from Internet: http://www.ejbiotechnology.info/content/vol10/issue1/full/ 6/index.html. ISSN 0717-3458. 